\title{
Hubungan Pelaksanaan Manajemen Laktasi oleh Petugas Kesehatan terhadap ASI Eksklusif pada Ibu Menyusui
}

\author{
Achmad Djamil $^{1}$, Nur Sefa Arief Hermawan ${ }^{2}$, Setiarini Nyke ${ }^{3}$ \\ ${ }^{1,2}$ Program Studi Kesehatan Masyarakat, STIKES Mitra Lampung, Indonesia \\ ${ }^{3}$ Puskesmas Krui, Kabupaten Pesisir Barat Lampung, Indonesia \\ Email: babedjamil@gmail.com
}

\begin{abstract}
Relationship of Lactation Management Implementation by Health Officers to Exclusive Breastfeeding in Breastfeeding Mothers. Nationally, exclusive breastfeeding coverage for infants aged less than six months was 55.7\%. Lampung province data for exclusive breastfeeding coverage in infants aged 0-6 months was still lower than the national age of 54.9\% and has not reached the target of Renstra 2015-2019 was 60\% (Ministry of Health RI, 2015). The purpose of this research was to know the relation of lactation management implementation by health officer to exclusive breastfeeding in breastfeeding mothers in Krui Pesisir West District of Lampung in 2017. This study was a quantitative research type, with the cross-sectional approach. The population was a lactating mother with a 0-6-month-old baby in region work Puskesmas Krui Pesisir West District, as many as 60 people. Data collection were using observation sheets. Data analysis was by bivariate using chi-square. The results of the study showed there was a relationship of lactation management implementation by health workers to exclusive breastfeeding in breastfeeding mothers at Krui Pesisir West District 2017 (p-value:0,031 and Odd Ratio: 5,37). The suggestion needs to improve education again as well as motivation on the importance of exclusive breastfeeding for breastfeeding mothers and to be more proactive in evaluating the implementation of exclusive breastfeeding coverage during breastfeeding mothers, with the aim of increasing the coverage of exclusive breastfeeding in infants aged 0-6 months.
\end{abstract}

Keywords: Lactation Management, Exclusive Breastfeeding, Breastfeeding Mothers

\begin{abstract}
Abstrak: Hubungan Pelaksanaan Manajemen Laktasi oleh Petugas Kesehatan terhadap ASI Eksklusif pada Ibu Menyusui. Secara nasional, cakupan pemberian ASI eksklusif pada bayi usia kurang dari enam bulan sebesar 55,7\%. Data provinsi Lampung untuk cakupan ASI eksklusif pada bayi umur 0-6 bulan masih lebih rendah dari nasional yaitu 54,9\% dan belum mencapai target Renstra 2015-2019 yaitu 60\% (Kemenkes RI, 2015). Tujuan penelitian untuk mengetahui hubungan pelaksanaan manajemen laktasi oleh petugas kesehatan terhadap ASI eksklusif pada ibu menyusui di Puskesmas Krui Kabupaten Pesisir Barat Lampung Tahun 2017. Jenis penelitian kuantitatif, dengan pendekatan cross-sectional, populasi adalah ibu menyusui dengan bayi berusia 0-6 bulan di wilayah kerja Puskesmas Krui Kabupaten Pesisir Barat, yaitu sebanyak 60 orang. Pengumpulan data dengan menggunakan lembar observasi. Analisa yang digunakan untuk bivariat menggunakan chi square. Hasil penelitian ada hubungan pelaksanaan manajemen laktasi oleh petugas kesehatan terhadap ASI eksklusif pada ibu menyusui di Puskesmas Krui Kabupaten Pesisir Barat Tahun 2017 (p-value:0,031 dan OR:5,37). Saran perlu meningkatkan kembali edukasi dan juga motivasi mengenai pentingnya pemberian ASI eksklusif pada ibu menyusui serta lebih proaktif dalam melakukan evaluasi pelaksanaan cakupan ASI eksklusif saat ibu menyusui dengan tujuan meningkatkan cakupan pemberian ASI eksklusif pada bayi usia 0-6 bulan.
\end{abstract}

Kata kunci: Manajemen Laktasi, ASI eksklusif, Ibu Menyusui

Secara nasional cakupan pemberian ASI eksklusif pada bayi usia kurang dari enam bulan sebesar 55,7\%. Berdasarkan data dinas kesehatan Provinsi Lampung, untuk cakupan ASI eksklusif pada bayi umur 0-6 bulan masih lebih rendah dari angka nasional yaitu baru sebesar $54,9 \%$ dan belum mencapai target Renstra 2015-2019 yaitu $60 \%$ (Kemenkes RI, 2015). Sedangkan Kabupaten Pesisir Barat merupakan daerah dengan cakupan pemberian ASI eksklusif terendah yaitu sebesar 36,1\% (Profil Dinas Kesehatan Provinsi Lampung, 2015).

Manajemen laktasi oleh tenaga kesehatan merupakan faktor pendukung keberhasilan pemberian ASI. Manajemen laktasi merupakan segala daya upaya yang dilakukan untuk membantu ibu mencapai keberhasilan dalam menyusui bayinya. Usaha ini dilakukan dalam 
tiga tahap, yaitu pada masa kehamilan (antenatal), sewaktu ibu dalam persalinan sampai keluar rumah sakit (perinatal), dan masa

Menyusui dalam hal ini memberikan ASI eksklusif merupakan cara yang terbaik untuk bayi karena ASI mudah dicerna dan memberikan gizi dalam jumlah yang cukup untuk kebutuhan bayi. Air Susu Ibu membantu melindungi bayi dari berbagai penyakit dan infeksi, membantu mencegah alergi makanan. Menyusui lebih nyaman dan lebih murah dari pada susu formula. ASI selalu siap dan pada suhu yang stabil dengan temperatur tubuh. Pada keadaan normal semua wanita dapat menyusui (Proverawati, 2010).

Tujuan umum penelitian ini adalah untuk mengetahui hubungan pelaksanaan manajemen laktasi oleh petugas kesehatan terhadap ASI eksklusif pada ibu menyusui. Sedangkan tujuan khusus penelitian ini adalah diketahuinya distribusi frekuensi pelaksanaan manajemen laktasi oleh petugas kesehatan, diketahuinya distribusi frekuensi pemberian ASI eksklusif oleh ibu menyusui dan diketahuinya hubungan pelaksanaan manajemen laktasi oleh petugas kesehatan terhadap ASI eksklusif pada ibu menyusui.

\section{METODE}

Jenis penelitian ini adalah kuantitatif. Desain yang digunakan menggunakan rancangan cross-sectional. Data dianalisis dengan uji chisquare. Populasi penilitian ini adalah seluruh ibu menyusui dengan bayi berusia 0-6 bulan di wilayah kerja Puskesmas Krui Kabupaten Pesisir Barat.

\section{HASIL}

\section{A. ANALISIS UNIVARIAT}

Tabel 1. Distribusi Pelaksanaan Manajemen Laktasi Oleh Petugas Kesehatan

\begin{tabular}{lcc}
\hline Manajemen Laktasi & n & \% \\
\hline Baik & 13 & 21,7 \\
Kurang Baik & 47 & 78,3 \\
\hline Total & 60 & 100 \\
\hline
\end{tabular}

Tabel 2. Distribusi Pemberian ASI Eksklusif oleh Ibu Menyusui

\begin{tabular}{lcc}
\hline Pemberian ASI Eksklusif & n & \% \\
\hline ASI Eksklusif & 28 & 46,7 \\
Tidak ASI Eksklusif & 32 & 53,3 \\
\hline Total & 60 & 100 \\
\hline
\end{tabular}

menyusui selanjutnya sampai anak berumur 2 tahun (postnatal) (Maryunani, 2015).

\section{B. ANALISIS BIVARIAT}

\begin{tabular}{|c|c|c|c|c|c|c|c|c|}
\hline \multirow{3}{*}{$\begin{array}{cc}\text { Tabel 3. } & \mathbf{I} \\
& \mathbf{I} \\
& \mathbf{T} \\
\end{array}$} & \multirow{3}{*}{\multicolumn{2}{|c|}{$\begin{array}{l}\text { Hubungan } \\
\text { Laktasi } \\
\text { Terhadap } \\
\text { Menyusui }\end{array}$}} & \multicolumn{3}{|c|}{ Pelaksanaan } & \multicolumn{3}{|c|}{ Manajemen } \\
\hline & & & leh & & & & ehatan & \\
\hline & & & ASI & Eksk & usif & & a Ibu & \\
\hline \multirow{3}{*}{$\begin{array}{l}\text { Manajemen } \\
\text { Laktasi }\end{array}$} & \multicolumn{4}{|c|}{$\begin{array}{c}\text { Pemberian ASI } \\
\text { Eksklusif }\end{array}$} & \multirow{2}{*}{\multicolumn{2}{|c|}{ Total }} & \multirow{3}{*}{$\begin{array}{c}p- \\
\text { value }\end{array}$} & \multirow{3}{*}{$\begin{array}{c}\text { OR } \\
(95 \% \\
\text { CI })\end{array}$} \\
\hline & \multicolumn{2}{|c|}{$\begin{array}{c}\text { ASI } \\
\text { Eksklusif }\end{array}$} & \multicolumn{2}{|c|}{$\begin{array}{c}\text { Tidak } \\
\text { ASI } \\
\text { Eksklusif }\end{array}$} & & & & \\
\hline & $\mathbf{n}$ & $\%$ & $\mathbf{n}$ & $\%$ & $\mathbf{n}$ & $\%$ & & \\
\hline Baik & 10 & 76,9 & 3 & 23,1 & 13 & 100 & \multirow{3}{*}{0,031} & \multirow{3}{*}{$\begin{array}{r}5,37 \\
(1,30- \\
22,17)\end{array}$} \\
\hline $\begin{array}{l}\text { Kurang } \\
\text { Baik }\end{array}$ & 18 & 38,3 & 29 & 61,7 & 47 & 100 & & \\
\hline Total & 28 & 46,7 & 32 & 53,3 & 60 & 100 & & \\
\hline
\end{tabular}

\section{PEMBAHASAN}

\section{Pelaksanaan Manajemen Laktasi oleh Petugas Kesehatan}

Berdasarkan hasil penelitian diketahui bahwa pelaksanaan manajemen laktasi oleh petugas kesehatan kategori kurang baik yaitu sebanyak 47 orang $(78,3 \%)$ dan pemberian ASI eksklusif oleh ibu menyusui sebanyak 32 orang $(53,3 \%)$.

Menurut peneliti, sebagian besar manajemen laktasi oleh petugas kesehatan dalam kategori kurang baik disebabkan karena belum maksimalnya pelaksanaan manajemen laktasi oleh petugas kesehatan kepada responden.

Hasil penelitian ini sejalan dengan yang dikemukakan oleh Maryunani (2015), bahwa manajemen laktasi merupakan segala daya upaya yang dilakukan untuk membantu ibu mencapai keberhasilan dalam menyusui bayinya. Usaha ini dilakukan terhadap ibu dalam 3 tahap, yakni pada masa kehamilan (antenatal), sewaktu ibu dalam persalinan sampai keluar rumah sakit (perinatal), dan pada masa menyusui selanjutnya sampai anak berumur 2 tahun (postnatal).

Kemudian, jika dilihat dari akses terhadap pelayanan kesehatan, lokasi penelitian ini merupakan daerah yang cukup sulit dimana berdasarkan observasi beberapa responden akan menempuh jarak yang cukup jauh dan medan yang cukup sulit untuk mendapatkan pelayanan kesehatan. Penelitian ini sejalan dengan penelitian yang dilakukan oleh Ariwati (2014), tentang hubungan dukungan bidan tentang pemberian ASI eksklusif dengan perilaku pemberian ASI eksklusif di Wilayah Kerja Puskesmas Ambarawa Kabupaten Semarang, yang diperoleh bahwa sebagian besar responden 
kurang mendapat dukungan dari petugas kesehatan tentang ASI eksklusif yaitu 64,5\%.

\section{Pemberian ASI Eksklusif oleh Ibu Menyusui}

Berdasarkan hasil penelitian dapat diketahui bahwa sebagian besar responden tidak memberikan ASI eksklusif, yaitu sebanyak 32 orang $(53,3 \%)$.

Menurut peneliti, sebagian besar responden tidak memberikan ASI eksklusif disebabkan karena kurangnya kesadaran responden untuk memberikan ASI secara eksklusif. Kurangnya kesadaran ini dapat terjadi akibat kurangnya pemahaman responden tentang manfaat pemberian ASI secara eksklusif. Kurang pemahaman tersebut dapat disebabkan karena responden belum pernah memperoleh atau belum pernah terpapar informasi tentang ASI eksklusif baik dari petugas kesehatan atau dapat dikatakan manajemen laktasi oleh petugas kesehatan masih kurang. Berdasarkan prasurvey terhadap responden, informasi tentang ASI eksklusif juga kurang diperoleh dari buku ataupun internet. Selain itu, tingkat pendidikan juga dapat mempengaruhi pengetahuan dan pemahaman responden, dimana sebagian besar memiliki tingkat pendidikan SMP (50\%). Penelitian ini sejalan dengan penelitian yang dilakukan oleh Rahmawati (2015), dengan judul penelitian hubungan antara karakteristik ibu, peran petugas kesehatan dan dukungan keluarga dengan pemberian ASI eksklusif di Wilayah Kerja Puskesmas Bonto Cani Kabupaten Bone, diperoleh bahwa sebagian besar responden tidak memberikan ASI Ekslusif dengan proporsi $87,5 \%$.

\section{Hubungan Pelaksanaan Manajemen Laktasi oleh Petugas Kesehatan Terhadap ASI Eksklusif Pada Ibu Menyusui}

Hasil penelitian diperoleh bahwa ada hubungan pelaksanaan manajemen laktasi oleh petugas kesehatan terhadap ASI eksklusif pada ibu menyusui di Puskesmas Krui Kabupaten Pesisir Barat Tahun 2017 ( $p$-value $=0,031$ dan $\mathrm{OR}=5,37$ ).

Menurut peneliti, adanya hubungan pelaksanaan manajemen laktasi oleh petugas kesehatan terhadap ASI eksklusif pada ibu menyusui disebabkan karena pelaksanaan manajemen laktasi merupakan hal yang sangat penting dilakukan oleh petugas kesehatan kepada setiap ibu hamil. Hal ini penting dilakukan karena petugas kesehatan memiliki peranan yang penting dalam memberi edukasi dan juga motivasi kepada ibu hamil untuk membantu ibu mencapai keberhasilan dalam menyusui bayinya. Dalam pelaksanaannya, jika manajemen laktasi yang dilakukan oleh petugas kesehatan cukup baik, maka akan merubah pandangan dan perilaku ibu dalam pemberian ASI secara eksklusif kepada bayi nya, begitupun sebaliknya jika manajemen laktasi yang dilakukan oleh petugas kesehatan belum baik maka ibu menyusui akan mengalami kesulitan dalam memberikan ASI secara eksklusif kepada bayi nya.

Hasil penelitian ini sejalan dengan yang dikemukakan oleh Maryunani (2015), bahwa manajemen laktasi merupakan suatu tatalaksana yang mengatur agar keseluruhan proses menyusui bisa berjalan dengan sukses, mulai dari ASI diproduksi sampai proses bayi mengisap dan menelan ASI, yang dimulai pada masa antenatal, perinatal dan postnatal.

\section{SIMPULAN}

1. Sebagian besar responden dengan manajemen laktasi oleh petugas kesehatan dalam kategori kurang baik, yaitu sebanyak 47 orang $(78,3 \%)$.

2. Sebagian besar responden tidak memberikan ASI eksklusif, yaitu sebanyak 32 orang $(53,3 \%)$.

3. Ada hubungan pelaksanaan manajemen laktasi oleh petugas kesehatan terhadap ASI eksklusif pada ibu menyusui di Puskesmas Krui Kabupaten Pesisir Barat tahun 2017 ( $p$ value $=0,031$, dan $\mathrm{OR}=5,37$ ).

\section{SARAN}

Bagi petugas kesehatan di Puskesmas Krui Kabupaten Pesisir Barat, perlu meningkatkan kembali edukasi dan juga motivasi mengenai pentingnya pemberian ASI eksklusif pada ibu menyusui serta lebih proaktif dalam melakukan evaluasi pelaksanaan cakupan ASI eksklusif saat ibu menyusui dengan tujuan meningkatkan cakupan pemberian ASI eksklusif pada bayi usia 0-6 bulan. 


\section{DAFTAR PUSTAKA}

Ariwati. 2014. Hubungan Dukungan Bidan Tentang Pemberian ASI Eksklusif Dengan Perilaku Pemberian Asi Eksklusif Di Wilayah Kerja Puskesmas Ambarawa Kabupaten Semarang. [Skripsi]. Semarang: STIKES Ngudi Waluyo Ungaran. Tidak diterbitkan.

Dinas Kesehatan Provinsi Lampung. 2015. Profil Kesehatan Provinsi Lampung Tahun 2015. Bandar Lampung.

Kemenkes RI. 2015. Profil Kesehatan RI Tahun 2015. Jakarta: Kemenkes RI.
Maryunani. 2015. Inisiasi Menyusui Dini, ASI Eksklusif dan Manajemen Laktasi. Jakarta: PT. Trans Info Media.

Proverawati, Atikah. 2010. Kapita Selekta ASI dan Menyusui. Yogyakarta: Nuha Medika.

Rahmawati, A., Bahar, B., \& Salam, A. 2012. Hubungan Antara Karakteristik Ibu, Peran Petugas Kesehatan Dan Dukungan Keluarga Dengan Pemberian ASI eksklusif di Wilayah Kerja Puskesmas Bonto Cani Kabupaten Bone. [Skripsi]. Makassar: Program Studi Ilmu Gizi, Fakultas Kesehatan Masyarakat UNHAS. Tidak dipublikasikan. 